\title{
The social budget policy process in Russia at a time of crisis
}

\section{Khmelnitskaya, Marina}

Routledge

2018

Khmelnitskaya, M 2018, The social budget policy process in Russia at a time of crisis . in S Fortescue (ed.), The Russian Budget . Routledge , Abingdon, pp. 9-27 .

http://hdl.handle.net/10138/310797

acceptedVersion

Downloaded from Helda, University of Helsinki institutional repository.

This is an electronic reprint of the original article.

This reprint may differ from the original in pagination and typographic detail.

Please cite the original version. 


\title{
The social budget policy process in Russia at a time of crisis
}

\author{
marina.khmelnitskaya@helsinki.fi ${ }^{1}$
}

Book Chapter published in The Russian Budget, Fortescue, S. (ed.) 2019, Abingdon: Routledge, pp: 9-27

\section{Introduction}

«Просто денег нет сейчас. Найдем деньги - сделаем индексацию. Вы держитесь здесь, вам всего доброго, хорошего настроения и здоровья». ${ }^{2}$

During his visit to Crimea in late May 2016, Prime Minister Dmitry Medvedev, responding to a question about the indexation of pensions from a local pensioner, used the phrase cited in the epigraph above. Slightly modified from its original, the phrase "Денег нет, но вы держитесь" became an instant classic, inviting creative responses among the users of Russian social media. ${ }^{3}$ "There is no money, but you hang in (there)" encapsulates a host of issues related to the financing of Russian government obligations in the social sphere in conditions of a severe revenue shortfall. Following years of economic growth since the early 2000s, which brought budget expansions and rises in personal income interrupted only by the impact of the Global Financial Crisis (GFC), in the last two years Russian policy-makers have started making adjustments to the new economic reality. The crisis into which the Russian economy plummeted in the second half of 2014 arose chiefly from the twin shock of the drop in oil prices and the introduction of international sanctions in response to the Ukraine crisis but was precipitated by the weakening of the Russian economy during the period of stagnant growth in 2012-2013 (World Bank 2016).

The crisis hit Russian government finances as well as Russian households hard. According to Aleksei Kudrin, former finance minister who recently resumed an important policy-making role, ${ }^{4}$ the fall in the oil price has led to a 4 percent reduction in GDP. ${ }^{5}$ This is equivalent to the entire

\footnotetext{
${ }^{1}$ The author is grateful to Stephen Fortescue, Markku Kivinen, Vesa Korhonen, Ben Noble and the anonymous reviewer for this journal for their help and helpful comments to the earlier drafts of this article.

2 https://www.youtube.com/watch?v=WSq7oxM fyo.

3 http://fishki.net/1961862-deneg-net-no-vy-zdes-derzhites-kak-socseti-otreagirovali-na-slovamedvedeva.html

${ }^{4}$ https://www.youtube.com/watch?v=HYB7oD0esg0

5 The latest official Rosstat figures show that in 2015-2016 the GDP dropped by 3.1 percent. http://www.gks.ru/wps/wcm/connect/rosstat_main/rosstat/ru/statistics/accounts/\#
} 
education budget and more than its health-care budget. In addition, average real incomes over the period 2014-16 have declined. In 2015 average household incomes dropped by 4.1 percent, and 5.6 percent in 2016. Average monthly real wages were 100.7 percent of their level a year earlier, whereas real pensions were 96.6 percent compared to $2015 .{ }^{6}$ Official poverty levels increased from 11.2 percent in 2012 to 15.7 percent in the first half of 2016 (Burdyak and Grishina 2016). In conditions of declining incomes and consumption, most Russians are reliant on state social support, in the form of pensions, welfare benefits, and salaries of public sector employees (Maleva 2016: 16). In an environment of decreased budget revenues, declines in real incomes and high expectations associated with state social provision make budget cuts in the social sphere a highly contentious issue.

Social policy is important for the Russian state both in ideological and monetary terms. It has occupied an important place in strategic documents - notably Concept 2020 and Strategy 2020 and the May Decrees of Vladimir Putin. In these documents social policy is seen as an integral component of Russia's pursuit of a greater role on the global stage, economic development and security (Cooper 2012; Connolly 2013). This emphasis is due to a number of factors: the realization by policy-makers of Russia's extremely poor demographic outlook, the perception of the failings of the liberal social reforms introduced in the early 2000s, the growing developmental aspirations of the ruling elite, and electoral motives. All these factors have reinforced each other over the last decade to give special significance to social measures, leading the government to develop new policies and institutional structures in the social sphere. Even though over the last decade the growth of social spending was not out of proportion with the growth of the consolidated budget expenditure as a whole (Sutela 2012: 196-202 and Table 1 below), nonetheless it constitutes the state's largest expense item. Over 60 percent of consolidated budget outlays are directed to four broad sub-fields: (1) housing and housing services, (2) education, culture and mass media, (3) health and sport, (4) social security including pensions. In conditions of Russia's heightened international role social spending has to be balanced with other significant budgetary items, particularly defense spending, the share of which in the 2016 federal budget is 24 percent (Visloguzov 2016a). ${ }^{7}$ Drawing on examples from different areas of social policy, this paper concentrates on the two most contentious issues involving the social sphere in the crisis budget

\footnotetext{
${ }^{6}$ Rosstat http://www.gks.ru/wps/wcm/connect/rosstat main/rosstat/ru/statistics/population/level/\# and BOFIT

${ }^{7}$ Also see Cooper (2017), in this volume.
} 
process: the indexation of the salaries of state sector employees (biudzhetniki) and social payments, specifically old-age pensions and Maternity Capital, the latter by far the largest social benefit with implications for Russian demographic and housing policies.

The article builds on the academic literature covering Vladimir Putin's leadership, combined with a thorough reading of official government and media sources for the period since late 2014. The broad foundation for the article's argument derives from the comparative political science and social policy literatures, their institutionalist strand specifically - what can be summarized as "politics matters" in defining welfare arrangements (Cook 2007). This scholarship argues that the impact of structural factors, such as the effects of drastic reductions in state budget revenues on welfare policy decisions, is mediated by the influence of political factors. Thus, the article focuses on the interrelated influence of policy actors' interests and expert ideas in the negotiation of reductions in social spending, in conditions of Russia's non-democratic political regime.

Within the Russian studies literature the analysis follows "institutionalist" as opposed to "personality-based" explanations of the policy process in Russia (Fortescue 2015, 2017 [in this special issue], Remington 2015). This literature argues that the institutional structure of the dual executive, operating within an authoritarian political regime, leads to a slow and drawn-out process of consensus-building, the participants in which are bureaucratic agencies and non-state actors associated with them. There is a de facto partisan divide between left and right blocs of bureaucratic agencies which essentially act as representatives for societal constituencies. The president, who in this tradition is credited with setting the general direction of policy, reluctantly has to support one side to put an end to prolonged policy elaboration in which institutional policy-makers fear taking responsibility. The budget process occupies an important place in this policy dynamic, as the annual budget cycle provides impetus for actors to reach decisions (Remington 2014).

In terms of the aims and capacity of Russian social policy, this article speaks to arguments made by scholars of the Russian welfare state that in conditions of non-democratic politics, social policy priorities are defined by the interests of political and bureaucratic elites, rather than the popular representation of interests (Kivinen 2016; Sutela 2012; Cook 2007). Within this line of argument, however, it has been suggested that Russian social policy spending priorities have oscillated 
between fiscal conservatism expounded by the economic and financial bloc of government, and active social policy associated with the social bloc and "involving greater amount of funds being made available and targeted for social issues" (Kivinen 2016). This article presents evidence that qualifies this argument. It shows that actors usually viewed as adherents of monetary restraint, such as Aleksei Kudrin, have advocated greater state investment in such areas as education, healthcare, and higher living standards. Kudrin sees these as "productive" areas of social policy, investments in which contribute to the country's "human capital" and are indispensible for the creation of a knowledge-based economy. ${ }^{8}$ This is in contrast to "non-productive" spending, including unreformed pension provision, poorly targeted social benefits, and defence. ${ }^{9}$

The article first examines Russian social policy in terms of the interests and ideas of influential policy-makers. It identifies important administrative and policy structures in the social sphere. Specifically it refers to National Priority Projects, the May Decrees, and Priority Projects introduced during the summer of 2016. I then consider the process involved in defining indexation rates for biudzhetnik salaries, pensions, Maternity Capital and the freesing of contributions to the cumulative pension funds.

Table 1. Consolidated government budget* expenditures - social policy share of total expenditure, \%

$\begin{array}{cccccc} & \begin{array}{c}\text { Social } \\ \text { policy, } \\ \text { total** }\end{array} & \begin{array}{c}\text { Housing } \\ \text { and } \\ \text { communal } \\ \text { services }\end{array} & \begin{array}{c}\text { Education, } \\ \text { culture } \\ \text { and mass } \\ \text { media }\end{array} & \begin{array}{c}\text { Health and } \\ \text { sports }\end{array} & \begin{array}{c}\text { Social } \\ \text { security, } \\ \text { including } \\ \text { pensions }\end{array} \\ 2005 & 60,3 & 6,9 & 14,0 & 11,7 & 27,7 \\ 2006 & 61,8 & 7,5 & 14,6 & 11,5 & 28,2 \\ 2007 & 60,9 & 9,7 & 14,0 & 12,1 & 25,1 \\ 2008 & 59,6 & 8,1 & 13,9 & 10,9 & 26,6 \\ 2009 & 59,1 & 6,3 & 13,1 & 10,3 & 29,4 \\ 2010 & 63,6 & 6,1 & 12,8 & 9,7 & 35,1 \\ 2011 & 62,2 & 6,0 & 13,2 & 10,5 & 32,6 \\ 2012 & 61,7 & 4,6 & 13,0 & 10,7 & 33,4\end{array}$

\footnotetext{
${ }^{8}$ Such views are close to the findings of recent research on the "developmental state" which has emphasized the importance of a social policy component for successful industrial development (Evans 2014).

${ }^{9}$ Kudrin, speaking at the Sochi Forum, 30 September 2016, https://www.youtube.com/watch?v=HYB7oDOesg0.
} 


$\begin{array}{lllllc}2013 & 62,2 & 4,2 & 13,4 & 10,0 & 34,6 \\ 2014 & 58,5 & 3,6 & 12,9 & 10,1 & 31,9 \\ 2015 & 61,0 & 3,3 & 12,0 & 10,5 & 35,2 \\ 2016 * * * & 60-60,5 & 3,2 & 11,7 & 10,9 & \text { about 34,5 } \\ \text { * federal budget, regional and local budgets, and state social funds } \\ \text { ** sum of the four columns that follow } \\ \text { *** preliminary data }\end{array}$

Source: Russian Ministry of Finance and BOFIT

The sources of budget policy-making in the Russian social sphere

The position of key policy makers on social policy and its funding is a function of their internalized systems of values, expert advice and interest in popularity and electoral votes. The most powerful actor in the Russian policy process is Vladimir Putin, and his set of views generally determines the direction of budget policy, including in the social sphere. The fundamental beliefs of the President regarding the economy, specifically fiscal prudency and macro-economic stability, are important for an understanding of the president's policy preferences. Another key component of his outlook relates to the use of Russia's oil and gas wealth to spur economic development and the improvement of citizens' welfare. Those relying on the state budget for their income, such as teachers, doctors, scientists and pensioners, support the president. ${ }^{10}$ To these we may add such procedural features of Putin's style of governance as a belief in strategic documents - "the urge to plan" (Cooper 2012: 1) - and reliance on policy experts working in state ministries and affiliated non-state structures. Connected to this is what we could call "the urge to integrate", bringing together different levels of authority and policy areas when they bear on a specific problem, a process also mentioned by Cooper (ibid: 3$).{ }^{11}$

The attention to the social sphere during Putin's tenure has its roots in advice provided Russia by international institutions in the early 1990s, which was further elaborated in the "Gref programme"

\footnotetext{
${ }^{10}$ As well as those working at unprofitable enterprises in Russia's heartland, as long as they have employment and stability (Crowly 2015).

11 While popular in contemporary public policy thinking and practice, policy integration is a challenging task even in conditions of democracy and a well-functioning civil service. In Russia this approach to policy-making is further complicated by the weakness of formal institutions, lack of accountability, and corruption (Monaghan 2013, Huskey 2009).
} 
at the start of Putin's presidency (ibid, Cook 2007, Sutela 2012). The group of experts originally involved in producing the program were based in the purpose-built Center for Strategic Development (CSR), and included German Gref, El'vira Nabiullina, Yaroslav Kuzminov and Arkadiy Dvorkovich. They have remained in prominent state and affiliated positions throughout Putin's leadership. They, together with Aleksei Kudrin, a close colleague of Putin since their days in St Petersburg, have continued to be key defenders of tight monetary policy. This group of top policy-makers remains among the very few "to whom the president [actually] listens" (Orekhin 2016a). In 2016 Kudrin re-joined mainstream politics when elected deputy chair of the Presidential Economic Council and put in charge of writing a new strategy for Russia's development post-2018, which might become Putin's next pre-election program (Khamraev 2016). As of autumn 2016 Kudrin has taken an active role in the budget process (Kriuchkova and Butrin 2016a).

Policies developed by this group of reformers, including for the social sphere, were adopted in 2004. Yet, unexpectedly for them some of the measures, particularly the monetization of in-kind benefits, provoked mass protests by pensioners during winter 2004-05. Mass demonstrations prompted changes in social policy preferences towards a slower pace of reform and greater state intervention (Wengle and Russel 2008, Remington 2011). In addition, the increase in budget revenues due to rising oil prices allowed extra funds to be dedicated to social issues, producing an "oil-led" social policy (Cerami 2009). Yet, decisions on how the extra resources should be spent was determined by policy interests and ideas shared by influential actors at that time. The set-backs resulting from the popular protests threatened the top leadership's hold on power. This made them receptive to ideas expressed by many Russian social scientists outside the narrow circle mentioned above.

The alternative specialists argued that earlier policies failed to address important challenges facing the country: an unprecedented deterioration of living standards, a rapidly worsening demographic outlook, and the unaffordability for the majority of many social goods provided by market structures, including housing (Zavisca 2012, Khmelnitskaya 2015). A strong emphasis on social problems and a statist approach to solving them appeared in the presidential address to the national assembly in April 2005 (Putin 2005), in which the president called for several National Priority projects to improve health outcomes and birthrates, as well as educational standards and housing 
affordability. Cooper (2012: 3) traces to this period the interest in developing strategic plans linking Russia's international standing and economic development with demography and social policy.

Introduced in 2006, four National Priority Projects were supervised by Dmitry Medvedev and were developed in cooperation with the think tank associated with him, the Institute for Contemporary Development (INSOR) (www.insor-russia.ru/ru/priorities/national_priorities). The projects contributed to Medvedev's popular appeal among voters, including during his presidential term 2008-12. During his presidency the national projects, formulated as state programs, ${ }^{12}$ became a regular part of the Russian budget (Kivinen 2016). ${ }^{13}$

The electoral cycle of 2007-08 saw another policy innovation relating to the social sphere, as well as to the wider economy, specifically the creation of what came to be known as "institutions of development", state-sponsored organisations aimed at leveraging budget funding with private funds for specific policy tasks. In the housing sphere, for instance, two state Funds (fondy) were set up in 2007 and 2008 (Khmelnitskaya 2015). In creating these structures policy-makers responded to the view in specialist circles that state intervention is unavoidable as "poor" apartment owners were unable to afford critically needed major repairs to their apartment buildings. Yet, the populist motives of the ruling elite during the pre-election period should not be overlooked. The poor state of housing and persistent increases in housing charges have consistently been among the most concerning issues for the public (Levada-Tsentr 2015: 9).

Key policy-makers, their interests and ideas in the areas of social spending

The ideological position of Dmitry Medvedev during his presidency and after has been characterized as a discourse of modernization, innovation, and participatory forms of government.

\footnotetext{
12 For instance the state programme for housing, in its latest version from April 2014, available at http://www.minstroyrf.ru/trades/realizaciya-gosudarstvennyh-programm/29/.

13 Spending on national priority projects and federal targeted programs can be accessed at http://datamarts.roskazna.ru/razdely/rashody/.
} 
With input from his INSOR advisors and other experts, it is a position which had a significant regime-legitimising effect in the post-GFC environment (Feklyunina and White 2011). Social policy-making included a rapid increase in benefits and pensions in 2009-10, evident from Table 1. This could be seen as an anti-crisis measure as recommended by international financial institutions (Kivinen 2016). At the same time, it was reinforced by the paternalistic social ideas of then Prime Minister, Vladimir Putin. We may also perceive an echo of the advocacy of increased budget spending on "human capital" in the context of the need to create a knowledge-based economy, something popular among the expert community and to be found in strategic documents written in 2008 and 2012. The increase in spending described as the "+4 -2 manoeuver" envisaged greater funding for - according to Kudrin's terminology - the "productive" part of social policy: health and education as well as R\&D (Cooper 2012: 10, Connolly 2013: 7-8), at the expense of unreformed pensions and benefits and military and law enforcement spending. The importance of structural reforms, particularly in the area of pensions, was highlighted. Nonetheless, greater commitments to social spending in the aftermath of the GFC have generated policy challenges in the post-2014 period of budget consolidation.

Despite Medvedev's fascination with innovation-led growth, his personal role in promoting "active social policy" was modest. He lashed with Aleksei Kudrin, then finance minister in Putin's government, over the growth of military spending. Kudrin resigned in September 2011. Medvedev's influence has been primarily in the sphere of administration and maintaining a balanced policy discourse, with key priorities set within the other part of Russia's dual-executive. For instance, when presenting his report on the government's work to parliament in April 2014 - a month after the takeover of Crimea - Medvedev stressed that Russia has a right to follow its own path to development, but noted immediately after that the country nonetheless could not ignore the universal laws of economics (Khamraev and Oktiabrev 2014).

The emphasis on social policy as a means to invest in the country's human capital that appeared in the late 2000s and has remained strong to the present (Kuzminov et al 2015), provided the ideational basis for a series of articles published by Putin in 2011-early 2012 and the May decrees of 2012 that set the tone for his third presidential term. Five of eleven decrees were devoted to 
social issues: social support, healthcare, education and science, housing, and demographics. ${ }^{14}$ Apart from the provision of higher quality services and reaching certain targets for health and educational outcomes, the decrees contained a pledge to raise salaries of biudzhetniki - doctors, teachers and scientists - to levels above the regional average and comparable to those in the commercial sector.

Putin's discoursive commitment to the implementation of the May decrees ${ }^{15}$ has been maintained in recent years but came under pressure during the budget process in 2016. Progress in their implementation has been monitored by state-sponsored public organisations such as the All-Russian National Front (Kommersant 2015) and by the dedicated Presidential Commission on the Implementation of the May Decrees (Kolesnikov 2016). The sessions (zasedaniya) of the Commission have been highly publicized, as were government meetings (soveshchaniya) leading up to them (Kriuchkova and Manuilova 2016). This, paired with a series of executive dismissals and resignations - arguably the most visible being the resignation of Vladislav Surkov as deputy prime minister on the first anniversary of the May decrees - and recurring threats to introduce administrative and even criminal responsibility for officials failing to meet decree-related targets (Kozichev and Shelkovnikov 2016), demonstrates the important legitimacy-seeking element in policy commitments in the social sphere. It also highlights the difficulty of implementation through reliance on Putin's power vertikal' (Monaghan 2013). During the 2016 budget process the maintenance and further increase in biudzhetnik salaries became one of the most controversial topics.

In mid-2016, in circumstances of tough negotiations over the new three-year budget, parliamentary elections approaching in September, and presidential elections scheduled for 2018, the policymakers' concern for popularity led them to revive the somewhat forgotten instrument of Priority Projects. Eleven priority projects - not equivalent to the May decrees, but still relating to the social and business environment - were originally to cost the budget R160 billion. This was reduced to R150 billion (1 percent of budget spending) in the draft budget approved by cabinet on 13 October 2016, while another R100 billion was reserved for various purposes, including the priority projects

\footnotetext{
14 The decrees (Numbers 596-606) were signed by Vladimir Putin on 7 May 2012, the day of his inauguration to a third presidential term. As an example, Decree N 606 on demographic policy is available at http://www.kremlin.ru/acts/news/15257.

15 The real commitment to the implementation of May Decrees has not been and could not be complete. Some of the targets set by decrees - such as 50 percent labour productivity increase - had an element of wishful thinking about them and were not borne out by the Russian economic reality.
} 
(http://government.ru/meetings/24877/stenograms/, Butrin et al 2016). In nominal terms this is the same as that allocated to the original 2006 national priority projects (Netreba 2016a); in real terms the present sum of USD 2.4 billion is less than half the funding of ten years earlier (over USD 5.5 billion). ${ }^{16}$

In late June 2016 a new consultative body, the Council for Strategic Development and Priority Projects, chaired by the president and including important figures from the economic and financial bloc of the government, was set up and began immediate intensive work. ${ }^{17}$ Between July and early October six sessions of the Council were held, two of which were chaired by the president. The others, held as meetings of the Council's presidium, were chaired by Medvedev. At the earlier meetings held in August, it was announced that a new set of priorities would be formulated only in 2017 (Orekhin 2016a). Yet, by early October 2016, at a session of the Presidium of the Council held at the Sochi Economic Forum, eleven priority projects were discussed. This session of the Council, chaired by Medvedev and with the participation of regional governors, underlined the regional dimension in the eleven priority areas. Medvedev summarized the important electoral rationale behind the projects when he closeed the meeting with the following words:

We need results in the shortest term. You know what I am talking about, and hope you will do all that is necessary. In a year and a half people should be able to feel changes [for the good] in the spheres covered by our projects (http://government.ru/news/24742/).

First deputy prime minister Igor' Shuvalov has been put in charge of the projects' supervision. Shuvalov ${ }^{18}$ - a close colleague of Putin since the early 2000s and responsible for the financial and economic bloc of the government - is said to have a major influence over the president. Although seemingly he does not work directly with the social sphere, he supervises the Ministry for Construction (Minstroy) and affiliated "institutions of development" in the housing sphere. Thus, he is coordinating the government's work on housing affordability, a key socially-oriented policy issue. His policy position appears close to the fiscal conservatives within the economic and

\footnotetext{
16 Author's own calculations on the basis is figures cited in Netreba (2016a).

17 Members included from the economic-financial bloc: Kudrin, Siluanov, Uliukaev, but also the pro-growth presidential advisor Andrey Belousov and the president of Delovaya Rossiaya Aleksei Repik, and the head of the social bloc Ol'ga Golodets, see http://www.kremlin.ru/events/councils/by-council/1029/52297 18 For biography see http://government.ru/gov/persons/3/bio/
} 
financial bloc. For instance, he has been the driving force behind the recent initiative to "optimize" the institutions of development. This has meant reduced spending and increased supervision of state corporations and Funds. Putin spoke of the need to review these structures in his address to the Federal Assembly in December 2015 (Netreba 2016b). Work in that direction had already begun earlier in the year with Shuvalov's April directive to reduce spending for the previously mentioned housing Funds. ${ }^{19}$ Evidence that Shuvalov is pushing optimization hard is the fact that the construction ministry was the only ministry which undertook the reform and disclosed its spending on Funds, while the Ministry of Economics struggled to get any action from other sectoral ministries.

However, the fiscal conservatism which Shuvalov demonstrates co-exists with his close connection to pro-growth actors in and close to the government (in the broad sense): presidential advisor Andrei Belousov and members of the Stolypin Club and Delovaya Rossiya business association. Belousov was one of the original sponsors of the Agency for Strategic Initiatives (ASI) and has advanced the implementation of its projects (Freinkman and Yakovlev 2015: 362). Shuvalov, meanwhile, has worked closely with experts in the housing sphere who participated in such ASIsupervised initiatives as raising Russia's ranking in the World Bank's Doing Business Guide (ibid $361) .^{20}$

Like Belousov, Alexandra Levitskaya is a presidential advisor, but with a more direct involvement in social policy. Before her current appointment in 2013, she held senior posts within the government apparatus, at the Ministry of Economics in Putin's government, where she worked with Elvira Nabiullina, Belousov and Andrey Klepach, and at the Ministry of Health in the mid-2000s when she worked closely with Medvedev on National Priority projects (Grishin et al 2013). Described in some sources as a close associate of Shuvalov, ${ }^{21}$ and as "one of the most influential female politicians in contemporary Russia, whose experience and opinion is highly valued by the president and the government" (Chemezov 2014), Levitskaya keeps a low public profile compared to other vocal figures in the social bloc, Ol'ga Golodets in particular. She has participated in a great

\footnotetext{
${ }^{19}$ See The strategy of development of the joint institution of development in the housing sphere, from 26 February 2016, http://www.minstroyrf.ru/odata/council-of-state/11641/, page 5

20 See Igor' Shuvalov and other important actors in the housing sphere - minister of construction Mikhail Men', the head of the State Duma housing committee Galina Khovanskaya, and others - at an event at the Institute for Urban Economics, 4 June 2015, http://old.urbaneconomics.ru/news/index213b.html?mat id=1815\#.

${ }^{21}$ See http://echo.msk.ru/blog/echo rating/1504966-echo/
} 
variety of meetings with state and non-state organisations on diverse social issues, including housing, healthcare, childhood protection, ${ }^{22}$ youth, the elderly and disabled, as well as civil society development, including philanthropy and volunteering. ${ }^{23}$ The last issue received significant attention during the most recent presidential address to the Federal Assembly on 1 December 2016 (Putin 2016). It is almost never reported what Levitskaya says in these meetings, but she receives high praise from many sources - consider the above quote from Sergei Chemezov. She most likely acts as an important coordinator for social matters in the presidential administration and between it and other parts of the executive. As to whether she supports "active social policy", and therefore is opposed to budget cuts to "productive" social sectors, is difficult to say conclusively. It appears likely, though, that like Shuvalov Levitskaya holds pro-growth policy views.

By contrast, deputy prime minister for social issues Ol'ga Golodets, the head of the government's social bloc, is an outspoken public figure. She has a background in labor economics, and worked in high positions in large private companies (Norilsk Nickel) and regional administrations (Taimyr and Moscow), supervising personnel and social issues. She joined Medvedev's government in May 2012 (http://government.ru/gov/persons/186/bio/). Within the government Golodets supervises matters ranging from family policy and demography, healthcare, education, pensions, to life style and culture. She is a member of the government Budget Commission and presidential commissions and committees, notably the Council for Strategic Development and Priority Projects. In the recent period of budget consolidation Golodets protested against the freezing, cancellation or replacement with one-time payments of respectively biudzhetnik salaries, social benefits, Maternity Capital and pensions, as will be discussed below. On such questions she clashed with Anton Siluanov, Minister of Finance, and Aleksei Uliukaev, Minister of Economics, who took rigid positions on the indexation of social spending (Kuvshinova et al 2016). Even when decisions were seemingly taken, as at the 24 June 2016 session of the Budget Commission, Golodets insisted that negotiations continue. Together with other ministers in the social bloc, notably Veronika Skvortsova of the Ministry of Healthcare, Maxim Topilin of the Ministry of Labour, and Dmitriy Livanov of the Ministry of Education and Science, Golodets held out against economic and financial bloc pressure and their advocacy of stricter targeting, and the "scientific" evidence supplied by associated experts on the limited impact of social programs (Manuilova 2016a).

\footnotetext{
22 See, for instance, the session of the presidential coordination council for the national strategy for children 2012-17, http://xn--c1ackabuhcbecyrh.xn--p1ai/news/193.

${ }^{23} \mathrm{http://www.donorsforum.ru/reports/rabochaya-vstrecha-foruma-donorov-s-sovetnikom-prezidenta-po-}$ voprosam-ekonomicheskogo-razvitiya-i-sotsialnoj-sfery-aleksandroj-levitskoj/
} 
In these exchanges, defending "popular policies" is central, while what is less popular can be sacrificed to spending cuts. The social bloc is prepared to appeal to ideology, arguing that such policies as Maternity Capital (a large cash benefit to mothers with housing policy implications) are the quintessence of the current social priorities of the government, particularly with respect to stimulating births and thus addressing demographic problems. This measure, popular with the public and construed by social bloc officials as existentially important for the country, has been retained - albeit without indexation - in the next three year budget (Sapozhnikov 2016).

Protesting too hard, nonetheless, can be harmful, as Minister of Education Livanov learned when he was replaced by Olga Vasil'eva in early September $2016 .{ }^{24}$ At a budget meeting (soveshchanie) held by Medvedev on 29 July Livanov presented a report demonstrating that the reduction in spending on education envisaged in the Ministry of Finance's draft documents would cause significant damage to the higher education system and, moreover, would jeopardise the goal set in the May decrees to increase teachers' salaries (Netreba 2016c). Medvedev suggested that the two ministries resolve their differences between themselves. The process clearly failed, as Livanov resigned on 19 August, and his stance was later dismissed by Medvedev as an attempt to use a difficult situation to score political points. ${ }^{25}$ Nonetheless, Livanov's protest against budget cuts resonated with the public and was harmful for the government's popularity (Netreba 2016a). As a result, by late summer 2016 Medvedev's position as premier fell into doubt. His blunt statements about indexation of pensions as quoted at the beginning of this article and comments regarding teachers' salaries in early August did not help. ${ }^{26}$ The tension was to a certain degree defused by Livanov's dismissal. Yet, as Levada Centre data show the government's and Medvedev's personal ratings suffered badly (http://www.levada.ru/2016/12/15/dekabrskie-rejtingi-2/).

While prepared to fight hard over politically sensitive social spending, the social bloc is prepared to be more flexible over those budgetary measures which might be perceived as less "harmful" in terms of public opinion. In order to increase budget revenues, the social bloc suggested "learning

\footnotetext{
${ }^{24}$ Vasilieva joined the government from the Presidential Administration, where she worked in the department for civic projects.

${ }^{25}$ At Government zasedanie, 13 October 2016, http://government.ru/meetings/24877/stenograms/.

${ }^{26}$ See http://www.rline.tv/news/2016-08-04-vy-zhe-uchitelya-zachem-vam-dengi-sotsseti-kommentiruyutmedvedeva/ 4 August 2016 and https://www.youtube.com/watch?v=QFKiMgrVnYQ.
} 
from Belarus", by introducing a charge for "non-working" working age persons to cover the costs of social services used by them. The assumption is that these people are employed in the shadow economy. The suggestion was opposed by the Ministry of Economics as a measure that would immediately run into definitional issues. ${ }^{27}$ It and the Ministry of Finance supported a different approach to increasing the collection of social contributions. ${ }^{28}$ Other proposals were expected to be more popular with the public, including the suggestion of the social bloc to freeze salaries and gradually increase the retirement age for state officials (Manuilova 2016b). Generally, the Russian public negatively views rises in the remuneration of state officials (Gimpelson et al 2009: 231).

In some of its policy views the social bloc joins with those of the pro-growth actors around the Stolypin club. Golodets explicitly supports the initiatives of the latter because of the possible expansion of employment that their "Strategy of growth" would bring. She also has been involved in consideration of their proposals within the government's inter-departmental working group. ${ }^{29}$ Nevertheless, apart from potential gains in employment Golodets has not endorsed the central premises expressed by Stolypin Club members, Sergei Glaziev and Andrey Klepach ${ }^{30}$ in particular, involving monetary emission and reducing Central Bank base rates to boost business activity (Butrin 2016a). The social bloc's position is linked with the slow growth model based on internal demand applied in 2010-13. The financial and economic bloc, as can be seen in the MacroEconomic Forecast presented by the Ministry of Economics to a cabinet meeting on 21 April 2016 and which became the basis for the 2017-19 budget, aimed specifically to restrain biudzhetnik earnings. Their intent was to redirect funds from consumption towards investment (Butrin 2016b; Manuilova 2016c).

\footnotetext{
27 See Mintrud nameren prorabotat' kriterii dlia platel'shchkov "naloga na tuneyadstvo", 30 September 2016 17:03 available at https://rns.online/economy/Mintrud-nameren-prorabotat-kriterii-dlya-platelschikov-naloga-natuneyadstvo-2016-09-30/

${ }^{28}$ They backed the transfer of the administration of pension and other social taxes from the Pension Fund and other extra-budgetary funds to the Federal Tax Service to make the enforcement of tax collection more straightforward, improving the take up and thus budget revenues.

${ }^{29}$ See http://stolypinsky.club/2016/08/02/pozitsiya-stolypinskogo-kluba-mne-blizka-golodets-podderzhalaopponentov-minfina/ and http://stolypinsky.club/2016/10/19/titov-programma-stolypinskogo-klubastrategiya-rosta-v-yanvare-budet-predstavlena-prezidentu/ ; also see Orekhin 2016b

30 Sergei Glaziev and Andrey Klepach are members of the Stolypin Club presidium http://stolypinsky.club/prezidium/. In addition, since December 2016 Glaziev and Klepach have been on the research council of the newly formed P.A. Stolypin Institute for the Economics of Growth (Nikolaeva 2016, http://stolypinsky.club/2016/12/21/predstavlena-struktura-strategii-rosta/).
} 
The position of Aleksei Kudrin - who shares the same ideas as the key figures of the financial bloc, including Nabiullina, Siluanov and Gref in relation to monetary regulation - differs from theirs in relation to personal incomes and social spending. He adds an important "active social policy" component to the policies supported by the Ministry of Finance and the CBR. He has insisted on a change of emphasis in social spending priorities, towards those that enhance the development of human capital, and on introducing better means-testing and targeting for other social benefits. This policy, argue Kudrin and a group of experts at the Ministry of Finance's Financial Institute and at the Russian Academy for the National Economy and Public Administration (RANKhiGS), would in time generate considerable improvements in living standards (Manuilova 2016a, Orekhin 2016a, Butrin 2016a). As a politician, however, Kudrin has to search for ways to increase the popularity of the policy of retrenchment. This requires demonstrating "considerable improvement in living standards" in the very short term. As deputy chair of the Presidential Economic Council from midMay 2016 and having convened a meeting of one hundred important experts in early June (Khamraev 2016), he (or they) seem to have proposed the relaunch of the Priority Projects referred to earlier, with the Council for Strategic Development and Priority Projects being formed by the end of June.

\section{Indexation of social payments: salaries of public employees, pensions and Maternity Capital}

One of the most contentious questions permeating the budget process has been the indexation of social payments. This section considers how the actors examined above interacted in the budget policy process on this important matter. Indexation of social payments is an issue of high electoral salience: the government put off the usual spring amendments to the 2016 budget until autumn in order to postpone unpopular decisions relating to indexation until after the September parliamentary elections (Visloguzov 2016b). The indexation of biudzhetnik salaries, pensions and such important social payments as Maternity Capital has been the subject of clashes and negotiations between the social and economic-financial blocs of the government. The debate is whether and how much indexation would be affordable in changing economic circumstances, and which categories of social payments should be prioritized. 
The pledge to increase salaries of biudzhetniki - above all teachers, doctors and scientists - was, as noted, part of the May decrees adopted in 2012 and fits with the ideology of investing in human capital. However, as budget revenues dropped by nearly R3 trillion in 2015, a proposal to reduce or forego altogether the inflation-linked 5.5 percent indexation of biudzhetnik salaries was voiced by Minister of Finance Siluanov in early February 2015 (Faliakhov and Kalachikhina 2015). Yet, in that year the indexation of salaries did go ahead, as the government agreed an anti-crisis plan in which funding for the social sphere increased by 23.5 percent nominally and 14.4 percent in real terms (World Bank 2016: 17). The issue re-surfaced during budgetary discussions the next spring, when the government and then the Duma considered the Ministry of Economy's Forecast of MacroEconomic Development. The ministry proposed an investment-led growth model for the 2017-19 budget, which would restrain income growth in the budget sphere (Butrin 2016b, Manuilova 2016c). The aim was to increase the volume of investment in the economy from 3.8 percent in 2017 to 7.1 percent in 2019, when it would reach 24.1 percent of GDP and deliver economic growth of 4.5 percent. The other side of the "Russian economic miracle", however, would be the reduction of personal incomes by 3 percent and pensions by 4.8 percent. The ministry insisted that the supertight monetary policy conducted by the Ministry of Finance and CBR aimed at bringing inflation down to 4 percent in 2017 would soften the adverse effect of income reduction on the public.

The social bloc and Stolypin Club of pro-growth actors, as well as those who supported an "active social policy", strongly disagreed with such an attack on personal incomes. In April 2016 Klepach argued that, while low inflation and economic investment were important, a sharp reduction in social spending would lead to the impoverishment of those in public employment. This would inevitably drive down the quality of their work, which is counterproductive for Russia's growth and competitiveness in the global economy (Manuilova 2016d). Klepach proposed squaring the circle by increasing public borrowing. Ol'ga Golodets, speaking at the Federation Council in September, was equally disapproving, pointing out that there are working poor in Russia, evident in the salary levels of biudzhetniki. ${ }^{31}$ Kudrin also criticized reductions in spending for education and healthcare, and suggested a three-fold increase in borrowing for 2017-19. ${ }^{32}$ Sergei Naryshkin, speaker of the sixth State Duma, in searching for a publically acceptable form of budget cuts said that the

\footnotetext{
31 For instance http://www.aif.ru/money/economy/golodec osudila nalichie v rossii rabotayushchih no bednyh lyudey ${ }^{32}$ Rossia 24 reporting from Sochi Investment Forum, 30 September 15:54 
parliament might support freezing salaries of those employed in state administration, but would defend teachers' and doctors' earnings (Manuilova 2016d).

In the budget draft approved by the government in early October the indexation and raising of biudzhetnik salaries contained in the May decrees was left de facto unresolved. Only 30 percent of funding for this purpose was to come from the federal budget and 70 percent left for regional budgets (Butrin et al 2016), most of which were already deeply in debt (Zubarevich 2016). The executive, wary of being decisive on this sensitive issue, shifted the decision-making to the budget's second reading in the Duma in early December. There the Duma's committee for budget and taxation proposed limiting the growth of salaries for doctors to 5.4 percent instead of the suggested 10.6 percent. The rationale was to reduce the pressure on regional budgets (which according to the new budget would be credited from the federal budget at below-inflation interest rates) and avoid the situation where, in pursuit of increasing salaries, regions had to lay off teachers and doctors. The first protests against such developments took place in Moscow in late November. ${ }^{33}$ The next day a spokesman for Putin reacted by saying that no decision on capping the increase in biudzhetnik salaries had been made by the government or president, with the issue still being a matter of "soglasovanie" among different policy participants. Golodets then affirmed that doctors' and teachers' salaries would be twice the average regional salary in $2018 .^{34}$ The Duma adopted the budget law at the third reading two days following these exchanges, on 9 December. Budget sector employees' salaries will continue to be a battleground in the future.

Another, and for some the most fundamental question of the budgetary process in 2016, was the indexation of pensions. In 2015 pensions were indexed from 1 February at 11.4 percent. For 2016 Siluanov, as already mentioned, proposed the partial or zero indexation of social payments, including pensions (Faliakhov and Kalachikhina 2015). Pensions are the biggest cash transfer from the state to citizens in Russia (Remington 2011). Cash flows within the pension system amount to 9.8 percent of GDP. ${ }^{35}$ (See Table 2.) Three forms of pension (insurance, social and state) are distributed by the state to 43.2 million people. For the Russian authorities this is a large and politically active social group. The protests following the monetization of benefits are vividly

\footnotetext{
33 Pro et contra: Kak uluchshit' kachestvo meditsiny v Rossii?, 6 December 2016, Kommersant FM, 20:42

${ }^{34}$ For the Duma's budget committee proposal, Peskov's statement and Golodets' hopes see http://www.kommersant.ru/doc/3163811 7 December 2016

35 According to forecast Pension Fund spending for 2016 (Fedunenko et al 2016).
} 
remembered. The sensitive issue of partial indexation was considered by the government during 2015, and was announced by Medvedev at the 7 October meeting of the government's Budget Commission. In February 2016 a partial four percent indexation was paid. It was promised that a second indexation would be paid in the second half of the year, subject to the overall economic and social situation. The social bloc insisted on the second indexation according to inflation, meaning an indexation of 8.56 percent from 1 September 2016 (Netreba and Faliakhov 2016). Yet, over the summer, particularly at the 24 June meeting of the Budget Commission, the Ministry of Finance proposed that the second indexation should be replaced by a one-time payment. The social bloc continued to fight against this option during the late summer. The media reported that the final decision was taken personally by Putin and Medvedev. ${ }^{36}$ After a government meeting (soveshchanie) on 23 August Medvedev announced that pensioners would receive a one-time payment of five thousand rubles in January 2017, at a cost to the budget of R200 billion. ${ }^{37}$ The rationale pursued by the Ministry of Finance was that, unlike indexation, the one-time payment would not increase the entitlement base of current pensions, allowing the budget to save R1.3trln over 2017-19 (Netreba and Faliakhov 2016).

This was immediately followed by the announcement of "full indexation" in 2017. Defining what "full indexation" meant took some time. If during the summer of 2016 the Ministry of Finance's plans mentioned 5.9, 4.5 and 4 percent for 2017, 2018 and 2019 respectively (ibid), in September it proposed a "4-4-4" percent formula (Kriuchkova and Butrin 2016b). The final word was pronounced by President Putin. At a 6 October soveshchanie on social and economic issues Putin demanded full indexation of pensions at the current inflation rate (ibid). At the same time, he was receptive to suggestions from economic experts such as Kudrin regarding better targeting and means-testing of social payments. In line with this rationale, in the new budget working pensioners would not have their pensions indexed over the next three years, and pensioners residing abroad would not receive the five thousand ruble payment in January 2017.

Table 2. Balance of the Pension Fund of Russia, billion rubles

\footnotetext{
${ }^{36}$ See https://www.gazeta.ru/business/news/2016/08/17/n 9007235.shtml

37 See https://www.gazeta.ru/business/news/2016/08/23/n_9029717.shtml 


$\begin{array}{lrrrrrr} & \mathbf{2 0 1 1} & \mathbf{2 0 1 2} & \mathbf{2 0 1 3} & \mathbf{2 0 1 4} & \mathbf{2 0 1 5} & \mathbf{2 0 1 6} \\ \text { Revenues } & & & & & & \\ \text { all transfers received } & \mathbf{5 2 5 6} & \mathbf{5 8 9 0} & \mathbf{6 3 8 8} & \mathbf{6 1 5 9} & \mathbf{7 1 2 7} & \mathbf{7 6 2 5} \\ \quad \text { transfers from federal budget } & 2385 & 2823 & 2852 & 2415 & 3105 & 3367 \\ \text { total revenue minus all transfers received } & 2384 & 2820 & 2847 & 2413 & 3092 & 3355 \\ \text { Expenditures } & 2870 & 3067 & 3537 & 3744 & 4021 & 4258 \\ \text { Deficit (-) / Surplus (+) } & \mathbf{4 9 2 2} & \mathbf{5 4 5 1} & \mathbf{6 3 7 9} & \mathbf{6 1 9 0} & \mathbf{7 6 7 0} & \mathbf{7 8 3 0} \\ & \mathbf{3 3 4} & \mathbf{4 3 9} & \mathbf{1 0} & \mathbf{- 3 1} & \mathbf{- 5 4 4} & \mathbf{- 2 0 4}\end{array}$

Source: Ministry of Finance, Rosstat and BOFIT

In recent years another controversial and related issue has been the freezing of the saving component of the pension system. ${ }^{38}$ This measure, first taken in 2013 , has changed the cash flows in the pension domain and allowed the creation of a "Presidential reserve" fund (approximately R350 billion in 2016). Originally implemented on the insistence of the social bloc, the sum has been used to prop up the Pension Fund (PFR) deficit (see Table 2). According to reports the money was also used for the restructuring of the Crimean economy after annexation in March 2014 (Orlov 2014). In relation to this policy, the positions within the economic-financial bloc contradicted one another. While the Ministry of Finance was supportive, Minister of Economics Uliukaev over the entire period up until his dismissal in November 2016 continued to insist that the money should be used for economic development and previously frozen resources be released (ibid, Faliakhov and Kalachikhina 2015, Rossia 24).

Plans for the gradual release of funds were discussed during 2016, accompanied by increased market activity and lobbying by independent pension funds (NPFs). The CBR, interested in forming a long-term funding capacity in the economy, has worked to improve the regulation and current operations of Russian NPFs (Aksenov 2016). The Ministry of Finance, while interested in removing the deficit but realizing the importance of the saving component given Russia's aging population, proposed a new scheme called "Pension capital". Its key feature was that funds saved by working individuals would remain their property, rather than being property of the Pension Fund (Fedunenko et al 2016). Pro-growth actors, Andrei Klepach for instance, while not dismissing this idea altogether, supported Uliukaev's position, insisting that “defreezing” of the savings component was

\footnotetext{
${ }^{38}$ For the recent - up to early-2015 - history of the issue and the policy process involved see Remington (2015). For the earlier period also see Sutela (2012) and Cook (2007).
} 
necessary to restore citizens' trust in the pension system, as well as to provide additional investment for the economy. ${ }^{39}$ If a partial release of funds were to go ahead, the NPFs would receive R60 billion in $2017 .{ }^{40}$ However, the social bloc was entirely opposed to the proposal, which would redirect revenues away from the Pension Fund. Golodets managed to defend this position during September, following the loss of the battle for the second indexation a month earlier. The "Basic directions of budget policy for 2017-2019”, considered by the government and the president in early October, included the continuation of the freeze, in which case budget transfer to the Pension Fund in 2017 would grow by R663.1 billion, while total holdings of the Fund would reach R8.18 trillion. $^{41}$

Finally we turn to the issue of the indexation of "Maternity Capital" (MC). Originally introduced in 2007 the measure is seen as a way to improve the birthrate by encouraging families to have more than one child. In the mid-2000s the birthrate was 1.3 births per woman. It had reached 1.78 by 2015 (Putin 2016). The MC has been also a component of Russian housing policy (Khmelnitskaya 2015), since one of the popular uses of the payment has been to buy property or take out or repay mortgage credit. MC at the time of its introduction was R250,000 and was paid from the Pension Fund. It was subject to annual indexation and by 2015 it had increased to R453,000, costing the Pension Fund R304 billion (Fedunenko et al 2016). Over the decade of the MC's existence, six million families have benefited and the amount paid was one trillion rubles (Manuilova 2016e).

The Ministry of Finance's idea to forego the indexation of biudzhetnik salaries and social payments affected the MC as well. A debate arose within expert and policy circles regarding its effectiveness with respect to both demography and housing policy. For instance, many reports of fraud involving MC money in the housing market have appeared in the newspapers (Goriacheva 2016). In the meantime, social policy experts from the Higher School of Eeconomics claimed that such measures were ineffective in stimulating births (Kuzminov et al 2015, Manuilova 2016e). Experts from RANKhiGS disagreed and advised that the measure should be continued as an important instrument of social support for families with children (Manuilova 2016e, Sapozhnikov 2016). The economic and financial bloc sided with the HSE experts and tried to eliminate the MC during 2015, a position

\footnotetext{
${ }^{39} \mathrm{https}$ ://rns.online/economy/Zampred-VEBa-Klepach-ne-verit-v-realizatsiyu-pensionnoi-modeli-Minfina-iTSB-2016-09-30/

40 see https://www.gazeta.ru/business/news/2016/09/27/n 9156221.shtml

41 see https://www.gazeta.ru/business/news/2016/10/07/n_9194969.shtml
} 
opposed by the social bloc. Putin in his state of the nation address in December 2015 supported the social bloc and said that the programme would continue until at least 2019 (Manuilova 2016e). The debate resurfaced as part of the budgetary process in 2016. In addition to the demands of the Ministry of Economics to close down the programme completely, new suggestions emerged from RANKhiGS specialists that it be means tested and/or divided into regional and federal components. The former component would be paid only in regions with low fertility. This would, for instance, exclude the North Caucasus Federal district where birthrates are high. As the discussion of the 2016 budget and the next three-year budget unfolded the social bloc, particularly the Ministry of Labour, emphasized the excellent results being delivered by the program (ibid, Sapozhnikov 2016). A month later it was confirmed that, as the social bloc insisted, the program would stay, although without indexation in 2016, leaving the payment at the 2015 level of R453,000. It remains to be seen how long this mass (6 million participants and voters), popular and expensive program will remain part of the budget. In contrast to the 2015 Presidential address, in December 2016 Putin spoke of "human capital" when he noted positive trends in Russian demographics; he also referred to "capital" in a financial sense a number of times. Yet there was no mention of the Maternity Capital program.

Budget issues in the social sphere are not restricted to indexation. In recent times policy-makers have been busy introducing other measures to both the spending and revenue sides of the social budget. In the housing sphere, important issues include major repairs, territorial development, mortgage funding, and the administration of property and land taxes - the last related to the revenue side of the budget. Structural reforms within the pension sphere - increasing the retirement age, reducing the number of early retirees, increasing the length of the employment requirement, cancelling pensions for working pensioners - as well as improving the collection of social contributions and reducing the shadow part of the economy are topics that have recurred during the budget process over the years, with the recent crisis years being no exception. While Putin's moratorium on tax increases during his current term in office has remained in place, certain tentative steps towards institutional reforms have, nevertheless, been taken recently: for example, decisions to increase the retirement age of state administration employees, to exclude the pensions of working pensioners from indexation, and to introduce administrative changes to the collection of pension contribution, to be carried out by the Tax Service from 2017. There is insufficient space in the present article to analyse these developments. Further research could examine how and to what effect Russian bureaucratic and societal actors, while negotiating the current retrenchment of the 
Russian welfare state (for comparative literature on retrenchment, see Pierson 1994), went about redefining the institutional foundations of the country's social policy.

Finally, we can briefly compare policy-making over the last two years involving social and economic-financial blocs pushing against each other while also trying to escape responsibility for tough decisions on social matters with budget policy-making during the crisis period of 2008-2009. Sutela (2012:164) argues that during that time: “... the debate between fiscal conservatism and development was won by social policy". The trend of increased social outlays associated with the period is evident in Table 1. Pointing to the importance of structural background of policy-making, Russian state finances were in a more robust condition in $2008^{42}$. However, the political factors were highly important. Vladimir Putin's premiership allowed manual control of the Russian government response to the global financial crisis, the response which effectiveness has been praised by international monetary institutions (ibid: 227). The authority locus at the Vladimir Putin's government meant that the Russian executive was less divided, with many influential policy-makers now scattered between its different parts (Nabiullina, Belousov, Klepach, Shuvalov and Levitskaya) and outside of it (Kudrin) working at Putin's ministries. Moreover, shared ideas, involving concern for social issues expressed in the Concept 2020 adopted in 2008 and supported by the paternalistic attitude of Prime Minister Putin - meant that both economic-financial and social wings of the government supported the increase in social spending, particularly pensions, introduced in March 2009, to prop domestic demand as a response to the crisis (Sutela 2012: 22223). This unity was not something the Russian executive displayed during 2014-2016.

\section{Conclusion}

The policy process traced in this paper generally approximates the view that policy-making in Russia begins with the President setting the general policy direction, which is followed by bureaucratic stakeholders and affiliated non-state actors becoming locked in battle to determine the details. The social budget policy-making analysed in this paper has been primarily concentrated within the executive. Within the executive, as far as the social sphere is concerned, the usual distinction that is drawn between supporters of monetary restraint and adherents of growth policies

\footnotetext{
42 Policy-makers relied on the large reserves in a form of the Stabilisation Fund, Rub 142.6bln on the eve of the crisis in September 2008 (Minfin data, Orekhin 2016a). During the current period the Russian Reserve and National Welfare Funds are expected to be gradually depleted (http://www.kommersant.ru/doc/3167919).
} 
is not quite straightforward. While a divide can be drawn between the economic-financial and social blocs of the government, the policy positions of the actors comprising these blocs vis-à-vis the diverse elements of social policy are intertwined in perhaps unexpected ways. For instance, Andrey Klepach, associated with pro-growth actors, and Alexei Kudrin, usually considered as a part of the financial bloc, have both supported increases in public borrowing in order to fund social spending. Together with Golodets, they have resisted freezing salaries for budget sphere employees, a Ministry of Finance proposal. At the same time, the attitudes of these actors towards the targeting of social benefits have varied. If fiscal conservatism, consistently promoted on behalf of the president by the Ministry of Finance, has represented the baseline for the social budget, the positions of other actors have mattered for defining details of current policies and setting future agendas, as with means-testing and targeting. The position of the social ministries led by vice-Premier Ol'ga Golodets in most cases amounts to resisting budget cuts whenever possible, but being flexible when the political sensitivity of a matter requires it, as in the case of indexation. President Putin interfered in the process only when the most salient and controversial issues were at stake, such as the indexation of pensions - but not biudzhetnik salaries, which were left as a matter of institutional "soglasovanie". For the president, prime minister and social bloc actors the pursuit of popular policies, that would demonstrate the utmost concern for the public welfare and generate popular support for the political regime, has been paramount.

\section{Bibliography}

Aksenov, P., 2016, Oboronka idet k Soglasiu, Kommersant, 25 April, p. 8

Burdyak, A. and Grishina, E., 2016, Income, poverty and prices: trends of 2016, in Gaidar Institute, Online Monitoring of Russia's Economic Outlook, N. 13 (31), July, pp.: 13-17, available at http://www.iep.ru/files/text/crisis_monitoring/2016_13-31_july_eng.pdf 
Butrin, D., 2016a, Ekonomicheskiy sovet skreplen liuboviu, Kommersant, 23 May, p. 2

Butrin, D., 2016b, God dobrovol'noy bednosti, Kommersant, 10 May, p. 1

Butrin, D., Kriuchkova, E. and Manuilova, A., 2016, Obeshchannogo tri goda ne zhdut, Kommersant, 13 October, p. 1

Cerami, A., 2009, Welfare state developments in the Russian Federation: oil-led social policy and the "Russian miracle", Social Policy and Administration, Vol. 43, No. 2, pp.: 105-120

Chemezov, S., 2014, Sovetniku prezidenta Aleksandre Levitskoy - 60 let, Nezavisimaya Gazeta, 14 April, http://www.ng.ru/politics/2014-02-07/2_congrats.html

Connolly, 2013, Economic growth and strategies for economic development in Russia, Russian Analytical Digest, No. 133, pp.: 5-9

Cook, L.J., 2007, Postcommunist Welfare States: Reform Politics in Russia and Eastern Europe, Ithaca: Cornell University Press

Cooper, J., 2012, Reviewing Russian Strategic Planning: the Emergence of Strategy 2020, Rome: NATO Defense College, Research Review

Cooper, J, 2017, The Russian budgetary process and defence: finding the 'golden mean', in Fortescue, S. (ed.), Special Issue on Russian Federal Budget Formation, Forthcoming in PostCommunist Economies, Vol. 29, no. 4 
Crowley, S., 2015, Monotowns and the political economy of industrial restructuring in Russia, Post-Soviet Affairs, DOI: 10.1080/1060586X.2015.1054103

Faliakhov, R. and Kalachikhina, Yu., 2015, Siluanov podrezhet biudzhetnikov, Gazeta.ru, 11 February, https://www.gazeta.ru/business/2015/02/10/6407849.shtml

Fedunenko, E., Zhuravlev, A. and Shelkovnikov, D., 2016, Chto nuzhno znat' o pensionnoy sisteme Rossii, Kommersant-online, 27 April 17:19

Feklyunina, V. and White, S., 2011, Discourses of 'Krizis': economic crisis in Russia and regime legitimacy, Journal of Communist Studies and Transition Politics, Vol. 27, No. 3-4, pp.: 385-406

Fortescue, S., 2016, Russia's "turn to the east": a study in policy making, Post-Soviet Affairs, Vol. 32, No.5, pp. 423-454

Fortescue, S., 2017, Budget formation in a semi-presidential system, in Fortescue, S. (ed.), Special Issue on Russian Federal Budget Formation, Forthcoming in Post-Communist Economies, Vol. 29, no. 4

Freinkman, L. and Yakovlev, A., 2015, Institutional frameworks to support regulatory reform in middle-income economies: lessons from Russia's recent experience, Post-Communist Economies, Vol. 27, No. 3, pp.: 354-369

Gimpel'son, V., Mogun, V. and Brym, R. J., 2009, Weberian ideals vs. Russian reality, in Rowney, D.K. and Huskey, E. (eds.), Russian Bureaucracy and the State: Officialdom from Alexander III to Vladimir Putin, Basingstoke: Palgrave Macmillan, pp.: 231-252

Goriacheva, V., 2016, Kapital lishili materinskikh prav, Kommersant, 11 May, p. 1 
Grishina, T., Khomraev, V., and Butrin, D., 2013, Aleksandra Levitskaya okupila terpenie, Kommersant, 3 August, p. 2

Khamraev, V., 2016, Aleksei Kudrin gotovit predlozheniya vysokoy stepeni soglasovannosti, Kommersant, 6 June, p. 3

Khamraev, V. and Oktiabrev, A., 2014, Dmitriy Medvedev otvetil na vse svoi voprosy, Kommersant, 23 April, p. 1.

Khmelnitskaya, M., 2015, The Policy-Making Process and Social Learning in Russia: the Case of Housing Policy, Basingstoke: Palgrave Macmillan

Kivinen, M., 2016, Financing the Welfare State System in Russia. In Aspalter, C. ed., Welfare regimes in Asia. Forthcoming

Kolesnikov, A., 2016, Maiskie kushchi, Kommersant, 17 May, p. 1

Kommersant, 2015, Bollee treti porucheniy iz maiskikh ukazov eshche ne vypolneny, Kommersant - online, 23 December, 16:48

Kozichev, E. and Shelkovnikov, D., 2016, Chto nuzhno znat' o maiskikh ukazakh, Kommersantonline, 16 May, 16:32

Kriuchkova, E. and Butrin, D., 2016a, Vse vernulos' na drugi svoya, Kommersant, 22 September, p. 1 
Kriuchkova, E. and Butrin, D., 2016b, Pushki, pensii, dolgi, Kommersant, 7 October, p. 2

Kriuchkova, E. and Manuilova, A., 2016, Otchet po nominalu, Kommersant, N. 81, 12 May, p. 2

Kuvshinova, O., Liutova, M. and Papchenkova, M., 2016, Biudzhet priniat, no ne poniat, Vedomosti , 26 June

Kuzminov, Ya.I., Ovcharova, L.N., Yakobson, L.I. (eds.), 2015, Social Policy: Long-term Trends and Recent Changes, Moskva: NIU VShE

Levada-Tsentr, 2015, Obshchestvennoe Mnenie 2014, Moskva: Levada Tsentr

Maleva, T. M., (ed.), 2016, Eszhemesiachniy Monitoring Sotsial'no-ekonomicheskogo Polozheniya i Samochuvstviya Naseleniya: 2015 - iyul' 2016, Moskva: RANKhiGS,

http://www.ranepa.ru/images/docs/monitoring/ek-monitoring/monitoring-august-2016.pdf accessed September 2016

Manuilova, A., 2016a, Pomoshchi nuzhen kontrol' i uchet, Kommersant, 20 April, p. 2

Manuilova, A., 2016b, Chinovnikov ostaviat na rabote, Kommersant, 23 April, p. 4

Manuilova, A., 2016c, Zarplatniy manevr, Kommersant-online, 10 May 2016, 12:20,

http://www.kommersant.ru/doc/2982687

Manuilova, A., 2016d, Rossii pridetsia narashchivat' dolgi, Kommersant-online, 19 April, 13:39, http://www.kommersant.ru/doc/2967790

Manuilova, A., 2016e, U indeksatsii nedetskoe litso, Kommersant, 19 October, p.: 2 
Monaghan, A., 2013, Putin's Russia: shaping a 'grand strategy'?, International Affairs, Vol. 89, No.

5, pр.: 1221-1236

Netreba, P., 2016a, Putin gotovit natzproekty k vyboram, Gazeta.ru, 13 September, https://www.gazeta.ru/business/2016/09/13/10191071.shtml

Netreba, P., 2016b, Instituty est', razvitiya net, Gazeta.ru, 29 August, https://www.gazeta.ru/business/2016/08/29/10164851.shtml

Netreba, P., 2016c, Obrazovanie v Rossii: bez studentov i uchenykh, Gazeta.ru, 31 July, https://www.gazeta.ru/business/2016/07/31/9722969.shtml

Netreba, P. and Faliakhov, R., 2016, Kak s''ekonomit' trillion, Gazeta.ru, 23 August, https://www.gazeta.ru/business/2016/08/23/10154525.shtml

Nikolaeva, D., 2016, “Strategiya rosta” obrela novye steny, Kommersant-online, 21 December, 01:51, http://www.kommersant.ru/doc/3176582

Orekhin, P. 2016a, Kogo slushaet president, Gazeta.ru, 25 August, https://www.gazeta.ru/business/2016/08/22/10152743.shtml

Orekhin, P., 2016b, Putinomika 4.0, Gazeta.ru, 16 August, https://www.gazeta.ru/business/2016/08/12/10122803.shtml

Orlov, A., 2014, Pensii rossiyan ushli v Krym, Gazeta.ru, 25 June, https://www.gazeta.ru/business/2015/02/10/6407849.shtml 
Pierson, P., 1994, Dismantling the Welfare State? Reagan, Thatcher and the Politics of Retrenchment, New York: Cambridge University Press.

Pravitel'stvo Rossii, 2016, Zasedanie prezidiuma Soveta pri Prizedente RF po strategicheskomu razvitiyu i prioritetnym proektam, 1 October, http://government.ru/news/24742/

Putin, V., 2005, Poslanie Federal'nomu Sobraniyu, 25 April, http://www.kremlin.ru/events/president/transcripts/22931, October 2016

Putin, V., 2016, Poslanie Federal'nomu Sobraniyu, 1 December, http://kremlin.ru/events/president/news/53379

Remington, T, 2011, The Politics of Inequality in Russia, New York: Cambridge University Press

Remington, T. F., 2014, Presidential Decrees in Russia: A Comparative Perspective, New York: Cambridge University Press

Remington, T., 2015, Pension reform in authoritarian regimes: Russia and China compared, available at https://www.semanticscholar.org/paper/Pension-Reform-in-Authoritarian-RegimesRussia-and-Remington/af163f68c90759c32c9942e843bc8eb865e7cfc5, accessed September 2016

Rowney, D., K., (2009), A D D $\quad$ T I T L E , in Rowney, D.K. and Huskey, E. (eds.), Russian Bureaucracy and the State: Officialdom from Alexander III to Vladimir Putin, Basingstoke: Palgrave Macmillan, pp.: A D D PAGES

Sapozhnikov, O., 2016, Materinskiy Kapital nel'zia ni reformirovat', ni uprazdniat', Kommersantonline, 06 September, 15:52, http://www.kommersant.ru/doc/3082403 
Sutela, P., 2012, The Political Economy of Putin's Russia, London: Routledge

Visloguzov, V., 2016a, Defitsit tsveta khaki, Kommersant, 18 October, p. 2

Visloguzov, V., 2016b, Gosduma - ne mesto dlia budzheta, Kommersant, 13 May, p. 1

World Bank, 2016, Russia Economic Report, N. 35, April,

http://documents.worldbank.org/curated/en/657991467989516696/pdf/104825-NWP-P156290-

PUBLIC-WB-RER-No-35-FINAL-ENG.pdf

Zavisca, J., 2012, Housing the New Russia, Ithaca \& London: Cornell University Press

Zubarevich, N. 2016, Regiony Rossii, in: Institut Gaidara, Monitoring Ekonomicheskoi Situatsii v

Rossii, N. 14 (32), September, pp.: 6-12, http://www.iep.ru/ru/publikatcii/publication/7997.html 